\title{
HARMONISASI UNDANG-UNDANG DASAR 1945 DENGAN KETENTUAN INTERNASIONAL TENTANG MASYARAKAT EKONOMI ASEAN 2015 (ASEAN Economic Community/AEC 2015)
}

\section{Harmonisation Constitution 1945 with International Conditions of the ASEAN Economic Community 2015}

\section{Desy Churul Aini}

Fakultas Hukum, Universitas Lampung

email: desychurulaini@yahoo.com

\begin{abstract}
One form of regional cooperation is followed by Indonesia with his participation as a member of ASEAN (Association of South East Asian Nations) which was established on the basis of the Bangkok Declaration, on 8 August 1967. By the $21^{\text {st }}$ century, ASEAN agreed to develop an integrated regional by forming a community of nations in Southeast Asia open, peaceful, stable and prosperous, mutual care, tied together in a dynamic partnership in 2020. Expectations are outlined in the ASEAN vision 2020 in Kuala Lumpur in 1997. To realize these expectations ratify ASEAN Bali Concord II at the $9^{\text {th }}$ ASEAN Summit in Bali in 2003 which approved the establishment of an ASEAN Community (ASEAN Community) and the target is accelerated into 2015. The result shows there is disharmony between 1945 to the international provisions of the AEC 2015 in which the rules on economic issues and social welfare in 1945 are listed in Chapter XIV National Economy and social welfare, Article 33 (1), (2), (3) and (4), while based on the AEC 2015 blueprint contains four pillar framework or MEA. Disharmony both conditions contained in 4 (four) things into focus, namely the harmonization of aspects of the legal principle, an agreement on the authority, goal setting and alignment settings on the environment and surrounding communities.
\end{abstract}

Keywords: Disharmony, the Constitution 1945, Asean Economic Community 


\section{abstrak}

Salah satu bentuk kerjasama regional yang diikuti oleh Indonesia adalah dengan keikutsertaannya sebagai anggota ASEAN (Association of South East Asian Nations) yang berdiri atas dasar Deklarasi Bangkok, pada tanggal 8 agustus 1967. Menjelang abad ke-21, ASEAN menyepakati untuk mengembangkan suatu kawasan yang terintegrasi dengan membentuk suatu komunitas negara-negara Asia Tenggara yang terbuka, damai, stabil dan sejahtera, saling peduli, diikat bersama dalam kemitraan yang dinamis di tahun 2020. Harapan tersebut dituangkan dalam visi ASEAN 2020 di Kuala Lumpur tahun 1997. Untuk merealisasikan harapan tersebut ASEAN mengesahkan Bali Concord II pada KTT ke-9 ASEAN di Bali tahun 2003 yang menyetujui pembentukan Komunitas ASEAN (ASEAN Community) dan target tersebut dipercepat menjadi tahun 2015. Hasil Penelitian menunjukkan terdapat disharmonisasi antara UUD 1945 dengan ketentuan internasional tentang MEA 2015 di mana aturan tentang masalah perekonomian dan kesejahteraan sosial dalam UUD 1945 tercantum dalam Bab XIV Perekonomian Nasional dan Kesejahteraan Sosial, Pasal 33 (1), (2), (3) dan (4), sementara berdasarkan cetak biru MEA 2015 ini memuat empat kerangka kerja atau pilar MEA. Disharmonisasi kedua ketentuan tersebut terdapat dalam 4 (empat) hal yang menjadi fokus harmonisasi yaitu dari aspek asas hukumnya, pengaturan tentang kewenangan, tujuan pengaturan dan keberpihakan pengaturan terhadap lingkungan dan masyarakat sekitar.

Kata Kunci: Disharmonisasi, UUD 1945, MEA

\section{A. Pendahuluan}

Pada dasarnya tujuan utama suatu negara melakukan hubungan internasional adalah untuk memenuhi kepentingan nasionalnya yang tidak dimiliki di dalam negeri. Untuk itu, negara tersebut perlu memperjuangkan kepentingan nasionalnya di luar negeri. Dalam kaitan itu, diperlukan suatu kerjasama untuk mempertemukan kepentingan nasional antarnegara. ${ }^{1}$

${ }^{1}$ Sjamsumar Dam, Riswandi. Kerjasama ASEAN Latar Belakang, Perkembangan dan Masa Depan. (Jakarta: Ghalia Indonesia, 1996), hlm. 15. 
Apabila suatu kerjasama dilakukan oleh negara-negara yang sama-sama terletak di wilayah tertentu, maka bentuk kerjasama tersebut disebut dengan kerjasama regional. Kerjasama regional merupakan kerjasama yang lebih mudah dilakukan untuk menuju cita-cita yang terkandung dalam globalisme, yaitu sebagai inspirasi ideal yang selalu jauh dari kenyataan politik internasional. Pada dasarnya kerjasama regional merupakan bentuk saling ketergantungan yang diatur berdasarkan kedekatan geografis yang bisa berkembang menjadi berbagai kepentingan bersama. Oleh karena itu, regionalisme merupakan tahap yang diperlukan masyarakat internasional dalam menuju globalisme yang dicita-citakan. ${ }^{2}$

Salah satu bentuk kerjasama regional yang diikuti oleh Indonesia adalah dengan keikutsertaannya sebagai anggota ASEAN (Association of South East Asian Nations) yang berdiri atas dasar Deklarasi Bangkok, pada tanggal 8 agustus 1967. Deklarasi ini menjadi awal penanda lahirnya sebuah organisasi antarnegara yang beranggotakan negara-negara di sebuah wilayah regional, Asia Tenggara. Deklarasi ini ditandatangani di Bangkok, Thailand, yang diwakilkan oleh lima wakil negara/pemerintahan negara-negara Asia Tenggara, yaitu:

1. Menteri Luar Negeri Indonesia, Adam Malik;

2. Wakil perdana Menteri merangkap Menteri pertahanan dan Menteri pembangunan Nasional Malaysia, Tun Abdul Razak;

3. Menteri Luar Negeri Filipina, Narciso Ramos;

4. Menteri Luar Negeri Thailand, Thanat Khoman; dan

5. Menteri Luar negeri Singapura, S Rajaratman.

Lima wakil negara tersebut melakukan pertemuan dan menandatangani Deklarasi ASEAN (The ASEAN Declaration) atau deklarasi Bangkok (Bangkok Declaration). Keanggotaan ASEAN kemudian berkembang menjadi sepuluh negara dengan masuknya Brunei Darussalam (1984), Vietnam (1995), Laos (1997), Myanmar (1997) dan Kamboja (1999). ${ }^{3}$

Menjelang abad ke-21, ASEAN menyepakati untuk mengembangkan suatu kawasan yang terintegrasi dengan membentuk suatu komunitas negara-

${ }^{2}$ Ibid., hlm. 17.

3 Departemen Luar Negeri Republik Indonesia (DEPLU RI), ASEAN selayang Pandang, Direktorat Jenderal Kerjasama ASEAN, (Jakarta: DEPLU RI, 2010), hlm. 2. 
negara Asia Tenggara yang terbuka, damai, stabil dan sejahtera, saling peduli, diikat bersama dalam kemitraan yang dinamis di tahun 2020. Harapan tersebut dituangkan dalam visi ASEAN 2020 di Kuala Lumpur tahun 1997. Untuk merealisasikan harapan tersebut ASEAN mengesahkan Bali Concord II pada KTT ke-9 ASEAN di Bali tahun 2003 yang menyetujui pembentukan Komunitas ASEAN (ASEAN Community) dan target tersebut dipercepat menjadi tahun 2015. Visi ASEAN ini, yaitu terdiri atas keinginan untuk membentuk Komunitas ASEAN yang terdiri dari 3 pilar utama, yaitu ;

\section{Komunitas politik-keamanan ASEAN (ASEAN Political-security Community/APSC)}

2. Komunitas Ekonomi ASEAN (ASEAN economic community/AEC)

3. Komunitas Sosial budaya (ASEAN Sosio-cultural Community/ASCC) ${ }^{4}$

Ketiga pilar tersebut saling berkaitan satu sama lain dan saling memperkuat tujuan pencapaian perdamaian yang berkelanjutan, stabilitas serta pemerataan kesejahteraan di kawasan. Konsep pelaksanaan dalam enam tahun pertama dipandu dengan Hanoi Plan of action (HPA) yang dikeluarkan pada 1998. Kemudian tahap selanjutnya adalah berlangsungnya KTT (Konferensi Tingkat Tinggi) ASEAN yang ke-10 di Vientiane, Laos tahun 2004, konsep komunitas ASEAN ini kemudian mengalami kemajuan dengan disetujuinya tiga rencana aksi (Plan of Action/ PoA) untuk masingmasing pilar yang merupakan program jangka panjang untuk merealisasikan konsep komunitas ASEAN. ${ }^{5}$ KTT ke-10 ASEAN juga mengintegrasikan ketiga rencana aksi komunitas ASEAN ke dalam Vientiane Action Program (VAP) sebagai landasan program jangka pendek-menengah untuk periode 2004-2010. Dari sisi kerjasama ekonomi, visi tersebut diwujudkan melalui strategi pengembangan ekonomi yang sejalan dengan aspirasi bangsa, dengan tujuan utama mencapai pertumbuhan ekonomi yang berkesinambungan dan merata, serta mendukung ketahanan individu negara anggota maupun kawasan. ${ }^{6}$

${ }^{4}$ Direktorat kerjasama ASEAN, Kenali ASEAN kita, (Jakarta: Kementerian Luar Negeri RI, 2008).

${ }^{5}$ Ibid.

${ }^{6}$ Sjamsul arifin, Rizal A Djaafara, Aida S Budiman. Masyarakat Ekonomi ASEAN 2015 Memperkuat Sinergi ASEAN di Tengah Kompetisi Globa, (Jakarta: Elex Media Komputindo, 2009), hlm. 2. 
Dalam perkembangan realisasi konsep MEA (Masyarakat ekonomi ASEAN) selanjutnya, dirumuskan tujuan akhir integrasi ekonomi, yakni mewujudkan ASEAN Vision 2020 pada deklarasi Bali Concord II, Oktober 2003. Pencapaian dilakukan melalui lima pilar, yaitu; aliran bebas barang dan jasa, investasi, tenaga kerja terampil, dan aliran modal yang lebih bebas. Berbagai kerjasama ekonomi dilakukan khususnya di bidang perdagangan dan investasi, dimulai dari Preferential Trade Arragement (PTA, 1977), ASEAN Free Trade Area (AFTA, 1992), ASEAN Framework Agreement on services (AFAS, 1995) dan ASEAN Investment Area (AIA, 1998), kemudian dilengkapi dengan perumusan sektor prioritas integrasi dan kerjasama di bidang moneter lain. Semua hal tersebut merupakan perwujudan dari usaha mencapai MEA. ${ }^{7}$

Pencapaian MEA memerlukan implementasi langkah-langkah liberalisasi dan kerjasama, termasuk peningkatan kerjasama dan integrasi di area-area baru antara lain; pengembangan sumber daya manusia dan peningkatan kapasitas (capacity building); konsultasi yang lebih erat di kebijakan makro ekonomi dan keuangan; kebijakan pembiayaan perdagangan; peningkatan infrastruktur dan hubungan komunikasi; pengembangan transaksi elektronik melalui e-ASEAN; integrasi industri untuk meningkatkan sumber daya regional; serta peningkatan keterlibatan sektor swasta. ${ }^{8}$

Keterikatan Indonesia dalam memberikan komitmennya untuk mencapai MEA 2015 memberikan arti bahwa Indonesia bersama-sama sembilan negara lainnya telah menyetujui untuk mencapai integrasi ekonomi regional sehingga Asean menjadi pasar tunggal dan kawasan produksi. Lima pilar penguatan yang dilakukan dari sisi ekonomi, yaitu aliran bebas barang, jasa, investasi, tenaga kerja terampil dan lebih bebasnya aliran modal di implementasikan secara bertahap sesuai dengan jadwal strategis yang telah disetujui bersama-sama. ${ }^{9}$ Komitmen tersebut membawa dampak diterapkannya paham liberalisasi dalam keseluruhan bidang perekonomian negara dalam hal ini adalah liberalisasi investasi, liberalisasi perdagangan, dan liberalisasi sektor jasa. Berkaitan dengan hal tersebut penulis tertarik

\footnotetext{
${ }^{7}$ Ibid.

${ }^{8}$ Ibid., hlm. 11.

${ }^{9}$ Ibid., hlm. 283.
} 
melihat bagaimana substansi tentang ketentuan tentang MEA ini dikaitkan dengan Undang-Undang Dasar 1945 (UUD 1945), di mana dikatakan bahwa UUD bersifat fundamental, hal-hal yang dimasukkan ke dalam UUD adalah segi-segi yang bersifat pokok, mendasar atau asas-asasnya saja. ${ }^{10}$

UUD 1945 merupakan hukum dasar dalam peraturan perundangundangan negara Indonesia. Yang dimaksud dalam hukum dasar adalah norma dasar bagi pembentukan peraturan perundang-undangan di bawah UUD RI tahun 1945. ${ }^{11}$ Oleh karena tingginya kedudukan UUD 1945 tersebut sudah seyogyanya berbagai perjanjian internasional yang diratifikasi oleh negara Indonesia harus sejalan dengan isi substansi materi muatan UUD 1945. Berdasarkan uraian tersebut penulis tertarik mengaji tentang Harmonisasi UUD 1945 dengan ketentuan internasional tentang Masyarakat Ekonomi ASEAN 2015 (ASEAN Economic Community/AEC 2015).

Pokok permasalahannya adalah apakah terdapat keharmonisan antara UUD 1945 dengan ketentuan internasional tentang MEA 2015 (ASEAN Economic Community/AEC 2015). Metode penelitian ini menggunakan pendekatan normatif serta analisis data yang menggunakan metode analisis secara deskriptif kualitatif.

\section{B. Pembahasan}

\section{Masyarakat Ekonomi ASEAN}

a. Pengantar

Masyarakat Ekonomi ASEAN (MEA) atau ASEAN Economic Community (AEC) merupakan konsep yang mulai digunakan dalam Declaration of ASEAN Concord II (Bali Concord II), Bali, Oktober 2003. MEA adalah salah satu pilar perwujudan ASEAN Vision, bersama-sama dengan ASEAN Security Community (ASC) dan ASEAN Socio-Cultural Community (ASCC). MEA adalah tujuan akhir integrasi ekonomi seperti dicanangkan dalam ASEAN Vision 2020:

... to create a stable, prosperous and highly competitive ASEAN economic region in which there is a free flow ofgoods, services,

\footnotetext{
10 Armen Yasir, Hukum Perundang-undangan, (Bandar Lampung: Justice Publisher, 2014), hlm. 118.

${ }^{11}$ Ibid., hlm. 120.
} 
investment, skilled labor and a freer flow of capital, pital, equitable economic development and reduced poverty and socioeconomic disparities in year 2020.

Pembentukan MEA dilakukan melalui empat kerangka strategis, yaitu pencapaian pasar tunggal dan kesatuan basis produksi, kawasan ekonomi yang berdaya saing, pertumbuhan ekonomi yang merata dan terintegrasi dengan perekonomian global. Upaya pencapaian masing-masing kerangka tersebut dilakukan melalui berbagai elemen dan strategi yang tercakup di dalamnya.

Pencapaian MEA melalui penciptaan pasar tunggal dan kesatuan basis produksi, ditujukan sebagai upaya perluasan melalui integrasi regional untuk mencapai Skala ekonomis yang optimal. Langkah-langkah integrasi tersebut (proses liberalisasi dan penguatan internal ASEAN) menjadi strategi mencapai daya saing yang tangguh dan di sisi lain akan berkontribusi positif bagi masyarakat ASEAN secara keseluruhan maupun individual negara anggota. Pembentukan MEA juga menjadikan posisi ASEAN semakin kuat dalam menghadapi negosiasi internasional, baik dalam merespon meningkatnya kecenderungan kerja sama regional, maupun dalam posisi tawar ASEAN dengan mitra dialog, seperti China, Korea, Jepang, AustraliaSelandia Baru, dan India.

Melalui proses integrasi ekonomi maka ASEAN secara bertahap menjadi kawasan yang membebaskan perdagangan barang dan jasa Serta aliran faktor produksi (modal dan tenaga kerja), sekaligus harmonisasi peraturan-peraturan terkait lainnya. Strategi pencapaian MEA mengacu pada Vientiane Action Programme (VAP) 2004-2010 yang merupakan strategi dan program kerja mewujudkan ASEAN Vision. Berdasarkan VAP, High Level Task Force-HLTF memberikan evaluasi dan rekomendasi untuk menjadikan ASEAN sebagai pasar tunggal dan basis produksi.

Secara umum, HLTF merekomendasikan pendekatan integrasi ekonomi melalui prosedur dan kebijakan baru untuk memperkuat implementasi beberapa inisiatif ekonomi yang sudah ada, termasuk ASEAN Free Trade Area (AFTA), ASEAN Framework Agreement on Services (AFAS) dan ASEAN Investment Area (AIA); mempercepat integrasi regional di sektor prioritas; memfasilitasi pergerakan tenaga kerja ahli dan bisnis; memperkuat institusi ASEAN, termasuk perbaikan lembaga ASEAN 
Dispute Settlement Mechanism dalam menjamin kecepatan dan kekuatan hukum apabila terjadi sengketa. Di luar itu, juga diupayakan agar integrasi ekonomi yang berlangsung memberikan manfaat bagi seluruh anggota ASEAN khususnya negara Kamboja, Laos, Myanmar dan Vietnam (atau disebut CLMV). Dengan strategi tersebut diharapkan negara ASEAN secara bersama-sama dapat mencapai MEA pada 2015.

Pencapaian MEA memerlukan implementasi langkah-langkah liberalisasi dan kerja sama, termasuk peningkatan kerja sama dan integrasi di area-area baru antara lain: pengembangan sumber daya manusia dan peningkatan kapasitas (capalty-building); konsultasi yang lebih erat di kebijakan makro-ekonomi dan keuangan; kebijakan pembiayaan perdagangan; peningkatan infrastruktur dan hubungan komunikasi; pengembangan transaksi elektronik melalui e-ASEAN; integrasi industri untuk meningkatkan sumber daya regional; serta peningkatan keterlibatan sektor swasta.

\section{b. Percepatan Pembentukan Masyarakat Ekonomi ASEAN 2015}

Cebu Declaration pada 13 Januari 2007 (12 ${ }^{\text {th }}$ ASEAN Summit) memutuskan untuk mempercepat pembentukan MEA menjadi 2015 guna memperkuat daya saing ASEAN dalam menghadapi kompetisi global, terutama dari China dan India. Beberapa pertimbangan yang mendasari hal tersebut adalah: (i) potensi penurunan biaya produksi di ASEAN sebesar 1020 persen untuk barang konsumsi sebagai dampak integrasi ekonomi ${ }^{12}$; (ii) meningkatkan kemampuan kawasan dengan implementasi standar dan praktik internasional, intelectual property rights, dan adanya persaingan. Dengan integrasi ekonomi diharapkan infrastruktur kawasan dapat lebih berkembang bersamaan dengan integrasi transportasi, telekomunikasi dan energi. Integrasi ekonomi juga memberikan manfaat bagi sektor swasta yang terlibat selama proses berlangsung. Dari evaluasi yang dilakukan terhadap 12 sektor prioritas integrasi, Sembilan diantaranya menyumbang lebih dari 50 persen perdagangan barang di ASEAN. Dengan demikian langkah percepatan integrasi ASEAN menjadi penting untuk memanfaatkan semua potensi yang ada.

12 McKinsey \& Company, ASEAN Competitiveness Study. (ASEAN Secretariat, 2003) 
Pada saat ini juga dilakukan upaya perjanjian kerja sama perdagangan antara ASEAN dan negara mitra dagang, yaitu China, India, Jepang, Korea, Australia, dan Selandia Baru. Semua perjanjian bilateral ASEAN tersebut pada saat realisasinya nanti diharapkan meningkatkan Skala ekonomi ASEAN dan mendukung daya saing ASEAN di pasar global. Pada akhirnya integrasi ekonomi menjadi langkah penting bagi pencapaian masyarakat ASEAN yang kuat dan berperan di masyarakat dunia. Ekonomi kawasan pada 2006 yang bernilai lebih dari USD \$1,1 triliun dengan populasi lebih dari 550 juta penduduk akan menjadi, tujuan yang semakin menarik bagi perdagangan dan investasi internasional.

Guna memperkuat langkah percepatan integrasi ekonomi tersebut, ASEAN melakukan transformasi "cara" kerja sama ekonomi dengan meletakkan sebuah kerangka hukum yang menjadi basis komitmen negara ASEAN melalui penandatanganan Piagam ASEAN (ASEAN Charter) pada KTT ASEAN ke-13, 20 November 2007. Bersamaan dengan penandatanganan Piagam ASEAN, cetak biru yang merupakan arah panduan MEA dan jadwal strategis tentang waktu dan tahapan pencapaian dari masing-masing pilar juga disepakati. Selanjutnya komitmen tersebut menjadi arah pencapaian MEA ke depan baik bagi ASEAN secara kawasan maupun oleh individu negara anggota. Masing-masing negara berkewajiban menjaga komitmen tersebut sehingga kredibilitas ASEAN semakin baik di masa depan. Secara teknis, monitoring mencapai pencapaian MEA dilakukan ASEAN Baseline Report. Beberapa kelengkapan tersebut menjadikan komitmen ASEAN dalam pencapaian MEA tidak lagi bersifat "persaudaraan" tetapi memunyai kekuatan hukum.

\section{c. Piagam ASEAN (ASEAN Charter)}

Setelah 40 tahun berdirinya ASEAN, bentuk kerja sama regional semakin diperkuat dan bertransformasi dengan ditandatanganinya Piagam ASEAN oleh para pemimpin negara ASEAN pada KTT ASEAN ke-13, 20 November 2007. Penandatangan Piagam ASEAN menjadi pratisi hasil evaluasi dari kerja sama yang bersifat "persaudaraan" menjadi organisasi yang berdasarkan suatu kerangka yang lebih kohesif berlandaskan rule based framework. Dengan kejelasan visi, tujuan, perbaikan struktur organisasi, pengambilan keputusan dan mekanisme dispute settlement serta peningkatan 
peran dan mandat Sekretariat ASEAN, diharapkan dapat lebih menjamin implimentasi kesepakatan-kesepakatan ASEAN yang telah dicapai.

Untuk mewujudkan harapan dan keinginan bersam ASEAN, yakni hidup damai, aman, stabil, makmur dan sejahtera, Piagam ASEAN merumuskan secara detail tujuan dan prinsip ASEAN. Tujuan yang ingin dicapai sejalan dengan tujuan MEA, yaitu (i) menciptakan ASEAN sebagai pasar tunggal dan kesatuan basis produksi; dan (ii) mengurangi kemiskinan dan kesenjangan pembangunan di antara negara anggota melalui bantuan dan kerjasama yang saling menguntungkan. ${ }^{13}$ Dalam hal prinsip kerja sama, ASEAN tetap memegang teguh prinsip yang telah dianut selama ini, yang intinya menghormati kedaulatan negara lain, tidak melakukan intervensi kebijakan dalam negeri negara lain, serta melakukan konsultasi secara insentif atas berbagai permasalahan regional.

Tranformasi mendasar yang dilakukan oleh Piagam ASEAN telah memberikan legal personality kepada ASEAN. Kini ASEAN sebagai organisasi kerja sama antarpemerintah memiliki identitas tersendiri terpisah dari identitas negara anggota ASEAN. Sebagai legal personality, ASEAN beraktivitas dan membuat perjanjian atas namanya dan dapat pula menuntut dan dituntut secara hukum. Sejalan dengan transformasi ini dilakukan pula penyempurnaan kelembagaan, sehingga ASEAN diharapkan dapat merespon lebih baik berbagai permasalahan regional dan global yang semakin kompleks di masa yang akan datang.

Badan pengambil keputusan tertinggi di ASEAN adalah ASEAN Summit Meeting (Konferensi Tingkat Tinggi/KTT), yakni forum yang terdiri dari Kepala Negara/Pemerintahan negara anggota. KTT ASEAN diselenggarakan satu tahun sekali di negara yang menjadi Ketua ASEAN. Masa jabatan Ketua ASEAN berlaku satu tahun dan dirotasi berdasarkan urutan alfabet.

13 ASEAN Charter. Chapter 1-To create a single marker and production base which is stabile, prosperous, bighty competive and economically integrated with effective fasilitation for trade and investmen in which there is free flow of goods, sevices and investment; fasilitated movement of business persons, professionals, talents and labar; and free of capital, and ti alleviate poverty and narrow the development gap within ASEAN trough mutual assistance and copperation. (Paragraf 5 dan 6). 
KTT ASEAN dibantu oleh ASEAN Coordinating Council yang terdiri dari menteri luar negeri ASEAN, yang melakukan pertemuan. paling sedikit 2 tahun sekali. Badan ini akan mengoordinasikan kebijakan, efisiensi dan kerja sama dalam mencapai masyarakat ASEAN dengan ASEAN Community Councils yang terdiri dari (i) ASEAN Political-Security Community Council, (ii) ASEAN Economic Community Council, dan (iii) ASEAN Socio-Cultural Community Council. Perkembangan dan rekomendasi pencapaian Masyarakat ASEAN dilaporkan kepada KTT ASEAN.

ASEAN Sector Ministerial Bodies merupakan badan di bawah koordinasi ASEAN Community Councils sesuai dengan masing-masing pilar dalam Masyarakat ASEAN. Badan ini akan melakukan kerja sama di masing-masing sektor dan mengimplementasikan keputusan-keputusan KTT ASEAN.

Dalam rangka mengefektifkan dan memfasilitasi proses integrasi dan implementasi keputusan, ASEAN Charter memperkuat kelembagaan ASEAN dengan meningkatkan peran dan mandat Sekretariat ASEAN. Sekretariat ASEAN akan dipimpin oleh Sekretaris Jenderal yang dipilih dalam KTT ASEAN untuk jangka waktu lima tahun dan kemudian dirotasi di antara negara anggota ASEAN secara urutan alfabet. Sekretariat Jenderal ASEAN akan berpartisipasi dalam semua pertemuan ASEAN mulai dari KTT sampai dengan Sector Ministerial Bodies. Sekretariat Jenderal juga dapat berpartisipasi dalam pertemuan ASEAN dengan pihak eksternal. Selain tugas-tugas tersebut, Sekretariat Jenderal ASEAN juga bertindak selaku Chief Administrative Officer of ASEAN.

Mengingat Sekretariat ASEAN bukan lagi representasi kepentingan masing-masing negara anggota, melainkan representasi kepentingan bersama di kawasan, maka ASEAN Charter menetapkan pembentukan dua badan yang dapat mewakili kepentingan masing-masing negara anggota yaitu: (i) Committee of Permanent Representatives to ASEAN dan (ii) ASEAN National Secretariats.

Setiap negara anggota akan menunjuk Committee of Permanent Representatives to ASEAN yang kedudukannya setingkat Duta Besar. Committee of Permanent Representative antara lain bertugas mendukung tugas ASEAN Community Councils dan ASEAN Sector Ministerial Bodies 
Berta melakukan koordinasi dengan ASEAN National Secretariat. Badan terakhir ini berfungsi melakukan koordinasi tingkat nasional di masingmasing negara dan menjadi national focal point. Komitmen dan mekanisme baru kelembagaan ASEAN telah memberikan keyakinan yang lebih besar bagi keberhasilan pencapaian tujuan ASEAN. Namun di sisi lain komitmen tersebut menuntut setiap anggota, termasuk Indonesia, untuk segera mempersiapkan diri, dari sisi kebijakan, kelembagaan maupun sumber daya manusia untuk berperan aktif dalam memberi arah dan warna kerja sama ASEAN di masa depan.

\section{d. Cetak Biru dan Jadwal Strategis MEA 2015}

Bersamaan dengan, ditandatangani ASEAN Charter, para pernimpin ASEAN juga menandatangani cetak biru MEA 2015 yang merupakan grand design MEA yang berisi jadwal strategis, yakni tahapan pencapaian dari masing-masing pilar MEA. Target waktu pencapaian MEA terbagi dalam empat fase yaitu 2008-2009, 2010-2011, 2012-2013 dan 2014- 2015. Cetak biru ini menjadi arah bagi kawasan maupun negara anggota untuk mencapai MEA 2015. Masing-masing negara berkewajiban untuk melaksanakan komitmen dalam cetak biru untuk membentuk kredibilitas ASEAN.

Mengingat pentingnya perdagangan eksternal bagi ASEAN dan strategi pembangunan ekonomi di negara ASEAN yang outward looking, cetak biru MEA memuat empat kerangka kerja atau pilar MEA, yaitu:

1) ASEAN sebagai pasar tunggal dan basis produksi internasional dengan elemen aliran bebas barang, jasa, investasi, tenaga kerja terampil, dan aliran modal yang lebih bebas;

2) ASEAN sebagai kawasan dengan daya saing ekonomi yang tinggi, dengan elemen peraturan kompetisi, perlindungan konsumen, hak atas kekayaan intelektual, pengembangan infrastruktur, perpajakan dan $e$ commerce;

3) ASEAN sebagai kawasan dengan perkembangan ekonomi yang merata dengan elemen pengembangan usaha kecil dan menengah, dan prakarsa integrasi ASEAN untuk negara-negara CLMV yang termuat dalam Initiative for ASEAN Integration; dan

4) ASEAN sebagai kawasan yang terintegrasi secara penuh dengan perekonomian global dengan elemen pendekatan koheren dengan 
ekonomi di luar kawasan, dan meningkatkan peran serta dalam jejaring produksi global.

Keempat pilar MEA saling berkaitan dan mendukung satu sama lain. ASEAN sebagai pasar tunggal dan basis produksi internasional harus memiliki daya saing ekonomi yang tinggi, baik sebagai kawasan dalam kerangka persaingan dengan kawasan/negara lain, maupun antar individu anggota. Untuk itu, kesenjangan pembangunan ekonomi antara negara anggota harus diperkecil sehingga playing field antar negara anggota menjadi setara. Hal ini perlu dilakukan mengingat globalisasi dapat memperbesar kesenjangan pembangunan yang secara potensial dapat menciptakan kerenggangan dan memperlemah solidaritas ASEAN. Manfaat integrasi yang dirasakan oleh seluruh anggota akan menjamin integrasi ekonomi yang berkelanjutan. Sebagai basis produksi internasional, maka pasar ASEAN yang terintegrasi secara penuh dengan pasar global menuntut pula koordinasi kebijakan eksternal antara negara anggota ASEAN.

Keterkaitan keempat pilar MEA tersebut membutuhkan koordinasi, konsistensi dan kesatuan arah elemen-elemen dari setiap pilar, dimulai dari perencanaan sampai dengan tahap implementasi. Untuk menjamin hal tersebut maka keempat pilar perlu didukung oleh riset, capacity building dan efektivitas kelembagaan ASEAN, serta komitmen kuat tiap negara.

Khusus untuk pencapaian pilar pasar tunggal dan kesatuan basis produksi, kelima elemen yang digunakan untuk pencapaiannya juga terkait erat dan saling mendukung antara satu dengan lainnya. Dalam kerangka pasar tunggal ASEAN, aliran barang dan jasa yang bebas di kawasan akan mendorong efisiensi produksi kawasan dalam kerangka supply chain. Kondisi tersebut akan membuka peluang lebih besar investasi lintas batas di dalam kawasan. Aliran bebas investasi akan membutuhkan aliran bebas tenaga kerja dan aliran modal yang lebih bebas, sebagai faktor produksi. Sebaliknya, aliran bebas investasi akan meningkatkan arus barang dan jasa yang digunakan sebagai bahan baku maupun produk akhir.

Secara teknis pencapaian MEA 2015 menggunakan mekanisme dan inisiatif yang telah dibentuk oleh ASEAN selama ini yang diperkuat dengan penguatan institusi dalam kerjasama ASEAN. Masing-masing institusi dan inisiatif yang terlibat di lima elemen pasar tunggal dan kesatuan basis produksi. Sebagai contoh, untuk elemen aliran bebas barang, inisiatif 
penurunan tarif dan non-tarif serta fasilitasi perdagangan menuju aliran bebas barang MEA 2015 didasarkan pada perkembangan dan penyempurnaan mekanisme yang ada mulai dari Prefential Tarif Arrangement (PTA), ASEAN Free Trade Area dan dilanjutkan oleh konsep cetak biru MEA. Hal yang sama juga terjadi untuk elemen-elemen lainnya di dalam pilar ini.

Cetak biru MEA juga memuat pedoman umum implementasi MEA yang dituangkan dalam jadwal strategis (Lampiran I). Implementasi MEA didasarkan pada prinsip "open, outward-looking, inclusive and marketdriven" dengan memperhatikan perbedaan tingkat pembangunan dan kesiapan anggota ASEAN melalui penerapan formulasi ASEAN minus negara X. Untuk menjamin pelaksanaan atas komitmen yang telah disepakati, terdapat prinsip tidak diperbolehkannya penarikan komitmen (no back-loading of commitments) dan terdapat fleksibilitas atas beberapa hal yang harus diajukan di awal perundingan serta disetujui bersama (preagreedflexibility).

\section{e. ASEAN Baseline Report}

Dalam rangka memantau kemajuan implementasi MEA disusun ASEAN Baseline Report (ABR) yang berperan sebagai scorecard dengan indikator kinerja utama yang dilaporkan setiap tahun oleh sekretaris jenderal ASEAN kepada para menteri dan kepala negara/pemerintahan semua negara ASEAN. ABR memuat kondisi dasar yang menjadi acuan evaluasi implementasi tiga pilar Masyarakat ASEAN (Keamanan, Ekonomi dan Sosial-Budaya), ukuran kemajuan kerjasama regional, dan panduan dalam mempersempit gap pembangunan antarnegara anggota. Tahun dasar yang digunakan adalah kondisi dan situasi ASEAN pada 2003, saat Bali Concord II dideklarasikan. Dengan ABR, antisipasi perbaikan yang dibutuhkan untuk menjamin keberhasilan pencapaian ASEAN Community dapat dilakukan sedini mungkin.

Secara teknis, ABR menyediakan analisis kuantitatif dengan indikator terpilih yang memenuhi kriteria: (a) memiliki relevansi tcrhadap kebijakan, (b) sederhana, (c) konsisten secara statistik, (d) valid, (e) ketersediaan data dan (f) cakupan indikator. Berbagai indikator tersebut diklasifikasikan menjadi tiga kategori, yaitu: indikator proses (process indicators), indikator 
output (output indicators) dan indikator hasil (outcome indicators), yang kemudian disusun menjadi indeks tingkat negara dan kawasan. Indeks tingkat negara digunakan untuk perbandingan antarnegara dalam pencapaian tujuan Masyarakat ASEAN. Sementara, indeks level kawasan digunakan untuk menilai kinerja secara keseluruhan kawasan pada setiap tujuan Masyarakat ASEAN.

Dalam pilar ekonomi, ABR menilai tingkat integrasi ekonomi di kawasan dalam perdagangan barang, jasa, investasi, tenaga kerja dan jasa pendukung seperti keuangan, informasi, teknologi komunikasi, transportasi serta infrastruktur. Sebagai contoh indikator integrasi perdagangan yang digunakan secara umum adalah: (i) perdagangan intra-ASEAN sebagai persentase dari total perdagangan, dan (ii) perdagangan intra-ASEAN sebagai persentase dari Produk Domestik Bruto (PDB). Pada tahun dasar 2003, perdagangan intra-ASEAN mencapai 22,1 persen dari total perdagangan ASEAN dibandingkan dengan 67,3 persen di Uni Eropa, 44,6 persen di NAFTA dan 14,9 persen di MERCOSUR. Sementara, pangsa perdagangan intra-ASEAN sebagai persentase PDB rata-rata mencapai sekitar 25 persen. Nilai tersebut di EU, NAFTA dan MERCOSUR masingmasing mencapai 38,5 persen, 10,3 persen dan 4,1 persen.

Kredibilitas penyusunan ABR ini sangat bergantung pada ketersediaan data di setiap sektor dan kemampuan setiap negara dalam penyusunan statistik dan manajemen database. Dengan tingkat pembangunan ekonomi yang berbeda, harmonisasi definisi variabel dan metode statistik menjadi suatu hal yang sangat penting untuk dilakukan.

\section{Tabel 1.}

\section{Rekomendasi Awal yang Dirumuskan HLTF}

\section{Rekomendasi Awal yang Dirumuskan HLTF}

High Level Task Force (HLTF) adalah unit kerja yang dibentuk guna merumuskan rekomendasi langkah-langkah yang diperlukan guna mencapai MEA, baik terkait dengan upaya liberalisasi maupun fasilitasi yang diperlukan. Rekomendasi tersebut terdiri dari langkah penguatan 
inisiatif yang sudah ada.

\section{Langkah Penguatan Inisiatif Kerja sama yang sedang berlangsung}

- Dibidang Perdagangan Barang

Guna mencapai arus perdagangan barang yang bebas antar kawasan maka diperlukan finalisasi konsep Rule of Origin (ROO); kejelasan langkah eliminasi hambatan non-tarif (Non-Tarif Measures); harmonisasi di kepabeanan (termasuk implementasi ASEAN Single Window untuk memproses elektronik dokumen perdagangan); percepatan implementasi Mutual Recognition Arrangements (MRAs) untuk lima sektor prioritas (peralatan listrik, kosmetik,farmasi, telekomunikasi, peralatan dan makanan jadi) dan sektor potensial lainnya; serta harmonisasi standar dan peraturan teknis lainnya.

- Perdagangan Jasa

Menggunakan pendekatan ASEAN-X formula dalam proses liberalisasi perdangan jasa; menyelesaikan MRAs untuk kualifikasi tenaga ahli dalam mendukung liberalisasi tenaga kerja ahli; serta melakukan serangkaian proses negosiasi guna pencapaian arus perdagangan jasa yang bebas di 2020.

- Investasi

Menerapkan ASEAN-X formulasi dalam mempercepat pembukaan sektor yang masuk ke dalam sensitive list; membangun jaringan antara kawasan perdagangan bebas ASEAN (free trade zone); dan upaya untuk meningkatkan aliran penanaman modal langsung (FDI) ke kawasan.

- Intellectual Prooerty Reights (IPRs)

Peningkatan kerja sama ASEAN yang lebih jauh dari trademark dan hak paten termasuk di bidang hak cipta (pertukaran informasi dan penerapan).

- Aliran Modal

Untuk memfasilitasi perdagangan dan investasi dan mempercepat implementasi roadmap integrasi ASEAN di bidang keuangan.

2. Langkah Inisiatif Baru 
- Mempercepat integrasi 11 sektor prioritas dengan negara koordinator, yaitu:

- Indonesia: produk berbahan kayu dan automotif,

- Malaysia: produk berbahan karet, tekstil, dan produknya,

- Myanmar: produk berbasis pertanian dan perikanan,

- Filipina: elektronika,

- Singapura: e-ASEAN dan perawatan kesehatan,

- Thailand: perjalanan udara dan turis.

- Pendekatan proses integrasi disektor prioritas didasarkan pada memadukan kekuatan individu negara guna keuntungan kewasan; memfasilitasi dan mendukung investasi intra-ASEAN; mempromosikan produk dan jasa "made in ASEAN".

- Menyusun roadmap untuk masing-masing sektor dengan memperhatikan keterlibatan sektor swasta.

- Menyusun langkah-langkah percepatan liberalisasi di perdagangan barang dan jasa.

- Memfasilitasi pergerakan terkait dengan bisnis dan pariwisata.

\section{Langkah Penguatan Institusi}

- Memperkuat mekanisme pengambilan keputusan di forum/unit yang telah dibentuk, seperti AEM (ASEAN Economic Minister) dalam mengordinasikan isu terkait dengan kerja sama dan integrasi keuangan, SEOM (Senior Economist Officials Meeting) untuk isu terkait teknikal/oprasional.

- Membentuk sistem yang efetif (advisory, konsultasi, dan mekanisme adjudicatory) guna menjamin pelaksanaan komitmen dan mempercepat penyelesaian sengketa.

- Meningkatkan kapasitas Sekretariat ASEAN dalam melakukan studi terkait dengan perdagangan, investasi dan keuangan

\section{Diseminasi}

- Meningkatkan kesadaran dan pemahaman isu ekonomi ASEAN pada dunia usaha, investor, maupun agen pemerintah.

\section{Pembangunan dan Kerja Sama Teknis}

- Diperlukan upaya untuk penyamaan tingkat pembangunan dan percepatan integrasi ekonomi negara CLMV. 


\section{Undang-Undang Dasar 1945}

Hukum positif pada umumnya disusun dalam pola tertentu agar dalam pelaksanaannya dapat dilakukan secara seksama. Pola yang banyak digunakan adalah hierarki (bertingkat), dari aturan yang paling tinggi sampai pada tingkat aturan yang paling rendah. Menurut pola ini seluruh struktur atau sistem hukum suatu bangsa terikat oleh susunan logis dari sekian banyak peraturan yang merupakan bagian-bagian yang membentuk sistem hukum bangsa-bangsa.

Hans Kelsen menjelaskan bahwa sistem atau bangunan hukum tersebut memunyai dasarnya dalam bentuk peraturan yang paling abstrak dan keseluruhan sistem hukum merupakan konkretisasi belaka dari peraturan yang abstrak melalui prinsip logika. ${ }^{14}$

Pemikiran Hans Kelsen ini dalam stuffentheory, jika dihubungkan dengan hierarki perundang-undangan maka di dalam sistem norma hukum negara Republik Indonesia, Pancasila merupakan norma hukum tertinggi sekaligus merupakan cita hukum (rechtidee). Pancasila yang dimaksud sebagaimana yang tertuang dalam pembukaan Undang-Undang Dasar 1945 (UUD 1945). Ini berarti pembukaan UUD 1945 merupakan norma dasar yang derajatnya tertinggi dalam negara atau norma fundamental negara (Staatsfundamentalnorm), yaitu norma yang merupakan dasar bagi pembentukan konstitusi atau UUD termasuk norma pengubahnya. Hakikat hukum suatu staatsfundamentalnorm ialah syarat bagi berlakunya suatu konstitusi atau UUD. Sedangkan, konstitusi dilihat dari teori keputusan Carl Scmid merupakan keputusan politik yang tertinggi di dalam negara yang disepakati oleh suatu bangsa.

Pasal-pasal dalam batang tubuh UUD 1945 dan putusan MPR (Majelis Permusyawaratan Rakyat) sesuai dengan ketentuan Pasal 3 Ayat 1 UUD 1945 putusan MPR disini adalah yang berhubungan dengan perubahan dan penetapan UUD serta dalam Hukum Dasar tidak tertulis (konvensi ketatanegaraan) merupakan aturan dasar atau aturan pokok negara yang

${ }^{14}$ Satjipto Rahardjo, Evaluasi terhadap KUHP baru, dilihat dari segi teori manajemen modern. Makalah seminar dalam rangka dies natalis Universitas Diponegoro, Semarang, 1983, hlm. 4, sebagaimana dikutip dalam Heryandi, Harmonisasi hukum pengelolaan pertambangan minyak dan gas bumi lepas pantai Indonesia, (Bandar Lampung: Penerbit Universitas Lampung 2011), hlm. 31. 
merupakan landasan bagi pembentukan undang-undang dan peraturan pelaksana lain yang lebih rendah. Peraturan perundang-undangan negara Republik Indonesia yang merupakan landasan bagi pembentukan undangundang dan peraturan pelaksana lain yang lebih rendah. Peraturan perundang-undangan negara republik Indonesia yang merupakan formell gezet (undang-undang) dan verordnung dan autonome satzungen (peraturan pelaksana dan peraturan otonom) yaitu peraturan perundang-undangan yang dibentuk DPR bersama-sama Presiden (yaitu UU) dan peraturan perundangundangan yang dibentuk lembaga pemerintahan lainnya yang dibentuk oleh undang-undang atau atas perintah undang-undang. Sedangkan peraturan pelaksana dan peraturan otonom dimulai dari peraturan pemerintah, peraturan presiden, peraturan menteri peraturan daerah dan peraturan perundangan yang lainnya atas perintah undang-undang.

Dengan demikian, prinsip perjenjangan suatu norma sesuai dengan prinsip pembentukan norma. Peraturan perundang-undangan bawahan senantiasa harus sejalan dan searah dengan norma peraturan perundangundangan yang lebih tinggi. Pembentukan norma suatu undang-undang misalnya, harus sejalan dan searah dengan norma dasar atau norma fundamental negara.

Kesesuaian norma hukum yang lebih rendah dengan yang lebih tinggi juga nampak dalam sejumlah asas yang dikenal dalam ilmu hukum. Asasasas tersebut biasanya dipergunakan dalam menyelesaikan konflik norma hukum. PW Brouwer et. al. Menyebutkan asas-asas penyelesaian konflik hukum yang dikenal dalam ilmu hukum antara lain:

a. Asas Lex Superior (Lex superior derogat legi inferior) : undang-undang yang lebih tinggi mengalahkan yang lebih rendah;

b. Asas Lex Specialis (lex specialis derogat legi generali): undang-undang khusus mengalahkan yang umum; dan

c. Asas Lex Posterior (lex Posterior derogat legi priori) : Undang-undang yang kemudian mengalahkan yang terdahulu. ${ }^{15}$

Indonesia sebagai bangsa yang selalu berhubungan dengan bangsa lain, tentu tidak dapat menutup (mengisolasi) diri dari pergaulan dengan bangsa-bangsa lain. Perkembangan bangsa-bangsa lain yang memiliki nilai

${ }^{15}$ Op. Cit., Armen Yasir, hlm. 18-19. 
hidup yang berbeda dengan bangsa Indonesia juga perlu diperhatikan agar bangun hukum Indonesia tidak berbenturan dengan kaidah hukum internasional. Oleh karenanya perkembangan perilaku masyarakat internasional yang sesuai dengan nilai-nilai yang tertuang dalam UUD 1945 sebagai staatsfundameltalnorm, perlu diakomodir dalam membangun sistem hukum Indonesia agar bangsa Indonesia tidak terkucilkan dari pergaulan masyarakat internasional, termasuk pengaruh positif dari globalisasi yang sedang melanda negara-negara di dunia dewasa ini, namun tidak semua hal yang berasal dari luar Indonesia harus diterima begitu saja, karena belum tentu sesuai dengan budaya bangsa Indonesia. Oleh sebab itu, nilai-nilai dalam UUD 1945 termasuk didalamnya adalah Pancasila inilah yang dapat dijadikan filter untuk menyaring berbagai budaya asing yang masuk yang tidak sesuai dengan budaya bangsa Indonesia dengan menempatkan nilainilai pembukaan UUD 1945 beserta batang tubuhnya dalam norma hukum. ${ }^{16}$

Berdasarkan dengan uraian tersebut dikaitkan dengan kesepakatan Indonesia sebagai negara anggota ASEAN dituntut untuk memiliki komitmen untuk tunduk di bawah kesepakatan yang telah dibuat melalui Declaration of ASEAN Concord II (Bali Concord II) yang dihasilkan pada pertemuan puncak ASEAN ke-9 di Bali. Para pemimpin negara ASEAN memproklamirkan pembentukan komunitas ASEAN (ASEAN community) yang terdiri atas tiga pilar, yakni komunitas keamanan ASEAN (ASEAN Security Community-ASC), komunitas ekonomi ASEAN (ASEAN Economic Community-AEC), dan komunitas Sosial budaya ASEAN (ASEAN sociocultural community-ASCC). ${ }^{17}$

Komitmen ini adalah sebuah komitmen yang harus dijalankan bersama sebagai sebuah bangsa yang bermartabat, sebagai bagian dari sebuah masyarakat internasional. Akan tetapi, melakukan filter atas kesesuaian antara kesepakatan internasional dengan menyaring berbagai budaya asing yang masuk dan tidak sesuai dengan budaya bangsa Indonesia dengan menempatkan nilai-nilai pembukaan UUD 1945 beserta batang tubuhnya dalam norma hukum adalah sebuah keharusan yang harus ditempuh untuk membangun sistem hukum Indonesia yang berorientasi pada

\footnotetext{
${ }^{16}$ Op. Cit., Heryandi, hlm. 29.
}

17 CPF Luhulima, Dewi F.A., Ikrar Nusa B, Yasmin S.,Ratna Shofi I, Masyarakat Asia Tenggara menuju komunitas ASEAN 2015. (Jakarta: P2P-LIPI dan Pustaka Pelajar), hlm. 5. 
nilai-nilai yang terkandung dalam pembukaan UUD 1945 termasuk di dalamnya Pancasila yang berfungsi sebagai pandangan hidup, ideologi negara, dasar negara dan sumber dari segala sumber hukum Indonesia yang harus dijadikan pedoman, nilai-nilai yang terkadung di dalam Pembukaan UUD 1945 harus terkandung di dalam setiap pasal yang ada pada setiap peraturan perundang-undangan. Termasuk menjadikan nilai-nilai tersebut ke dalam inti dalam gerak langkah diplomasi internasional Indonesia yang bebas aktif.

\section{Harmonisasi UUD 1945 dan Ketentuan Internasional tentang Masyarakat Ekonomi ASEAN 2015}

Harmonisasi setiap materi muatan peraturan perundang-undangan tersebut dilakukan sesuai dengan teori kebenaran menurut ilmu pengetahuan; (1) konsistensinya, yaitu antara materi muatan dalam peraturan yang satu dengan yang lain yang mengatur hal yang sama dirumuskan secara sama (taat asas); (2) koherensinya, yaitu materi muatan dalam satu peraturan harus menyatu (bertalian sebagai satu kesatuan) dengan materi muatan terkait dalam peraturan lain; dan (3) korespondensinya, yaitu materi muatan yang mengatur; objek, subjek, hak dan kewajiban, tugas dan fungsi dan lain-lain, pada bidang yang sama antara satu dengan yang lain harus berhubungan atau berkesesuaian. ${ }^{18}$

Berkaitan dengan uraian di atas berikut adalah deskripsi harmonisasi UUD 1945 dengan ketentuan internasional tentang masyarakat internasional. Undang-undang Dasar yang berkaitan dengan masalah perkenomian tercantum dalam Bab XIV Perekonomian Nasional dan Kesejahteraan Sosial, Pasal 33 sebagai berikut;

(1) perekonomian disusun sebagai usaha bersama berdasar atas asas kekeluargaan;

(2) cabang-cabang produksi yang penting bagi negara dan yang menguasai hajat hidup orang banyak dikuasai oleh negara;

(3) bumi dan air dan kekayaan alam yang terkandung didalamnya dikuasai oleh negara dan dipergunakan untuk sebesar-besar kemakmuran rakyat;

${ }^{18}$ Op. Cit., Heryandi, hlm. 14. 
(4) perekonomian nasional diselenggarakan berdasar atas demokrasi ekonomi dengan prinsip kebersamaan, efisiensi berkeadilan, berkelanjutan, berwawasan lingkungan, kemandirian, serta dengan menjaga keseimbangan kemajuan dan kesatuan ekonomi nasional; dan

(5)ketentuan lebih lanjut mengenai pelaksanaan pasal ini diatur dalam undang-undang.

Berdasarkan teori Hans Kelsen sebagaimana diuraikan sebelumnya, maka Pasal 33 (1), (2), (3), (4) dan (5) itulah yang menjadi dasar dalam melakukan berbagai kegiatan kebangsaan yang berkaiatan dengan masalah ekonomi dan kesejahtraan sosial termasuk menjadi filter dalam hal keikutsertaan Indonesia dalam memberikan komitmennya menjadi bagian dari Mayarakat Ekonomi ASEAN 2015.

Berdasarkan cetak biru MEA 2015 kita dapat melihat bagaimana bentuk perdagangan yang akan dibangun di ASEAN ini. Cetak biru MEA 2015 ini memuat empat kerangka kerja atau pilar MEA, yaitu;

a. ASEAN sebagai pasar tunggal dan basis produksi internasional dengan elemen aliran bebas barang, jasa, investasi, tenaga kerja terampil, dan aliran modal yang lebih bebas;

b. ASEAN sebagai kawasan dengan daya saing ekonomi yang tinggi, dengan elemen peraturan kompetisi, perlindungan konsumen, hak atas kekayaan intelektual, pengembangan infrastruktur, perpajakan dan $e$ commerce;

c. ASEAN sebagai kawasan dengan perkembangan ekonomi yang merata dengan elemen pengembangan usaha kecil dan menengah, dan prakarsa integrasi ASEAN untuk negara-negara CLMV yang termuat dalam Initiative for ASEAN Integration; dan

d. ASEAN sebagai kawasan yang terintegrasi secara penuh dengan perekonomian global dengan elemen pendekatan koheren dengan ekonomi di luar kawasan, dan meningkatkan peran serta dalam jejaring produksi global.

Disharmonisasi UUD 1945 Pasal 33 (1), (2), (3), (4) dan (5) dan cetak biru MEA 2015 secara sederhana akan digambarkan dan diuraikan sebagai berikut ; 
Tabel 2.

Disharmonisasi UUD 1945 Pasal 33 dengan Cetak Biru MEA 2015 dengan Tolok Ukur Harmonisasi dari Aspek Asas Hukum

\begin{tabular}{|l|l|l|}
\hline \multicolumn{1}{|c|}{$\begin{array}{c}\text { Fokus } \\
\text { Harmonisasi }\end{array}$} & \multicolumn{1}{|c|}{ UUD 1945 Pasal 33 } & \multicolumn{1}{c|}{ Cetak Biru MEA 2015 } \\
\hline ASAS & Butir 1: & Kerangka Kerja 1 : \\
HUKUM & $\begin{array}{l}\text { Perekonomian disusun } \\
\text { sebagai usaha bersama } \\
\text { berdasar atas asas } \\
\text { kekeluargaan. }\end{array}$ & $\begin{array}{l}\text { ASEAN sebagai pasar } \\
\text { tunggal dan basis produksi } \\
\text { internasional dengan } \\
\text { elemen aliran bebas } \\
\text { barang, jasa, investasi, } \\
\text { tenaga kerja terampil, dan } \\
\text { aliran modal yang lebih } \\
\text { bebas. }\end{array}$ \\
\hline
\end{tabular}

UUD 1945 Pasal 33 butir (1) tersebut dalam hal asas hukum mengharuskan bahwa perekonomian nasional harus berdasarkan asas kekeluargaan dengan konsep demokrasi ekonomi, di mana produksi dikerjakan oleh semua, untuk semua di bawah pimpinan/ kepemilikan anggota-anggota masyarakat.

Berbeda dengan cetak biru MEA 2015, cetak biru MEA mendorong terjadinya liberalisasi barang, jasa, investasi dan tenaga kerja. Liberalisasi ekonomi ini akan menciptakan terjadinya sebuah kompetisi yang tinggi antar negara yang akan berimbas kepada individu sebagai pengemban amanat sebagai warga negara. Kompetisi tinggi yang terjadi tersebut tidak memberikan ruang terhadap realitas adanya berbagai kesenjangan kemampuan dan kapasitas tiap-tiap individu atau warga negara di dalam kehidupan bermasyarakat. Hal ini akan menyebabkan terjadinya kerenggangan dan soliditas antar sesama warga negara. Rasa kekeluargaan sebagai bagian dari sebuah bangsa yang memiliki rasa senasib sepenanggungan sebagai salah satu nilai yang ingin ditanamkan dalam jiwa raga seluruh bangsa Indonesia menjadi terkikis. Sikap kekeluargaan adalah cita bangsa yang dituangkan oleh para pendiri bangsa sebagaimana 
tercantum di dalam UUD 1945 ini. Termasuk sikap tenggang rasa dan toleransi antar sesama anggota masyarakat yang merupakan salah satu ciri kepribadian bangsa Indonesia ini.

Tabel 3.

Disharmonisasi UUD 1945 dengan Cetak Biru MEA 2015 dengan Tolok Ukur Harmonisasi dari Aspek Pengaturan tentang Kewenangan.

\begin{tabular}{|l|l|l|}
\hline \multicolumn{1}{|c|}{$\begin{array}{c}\text { Fokus } \\
\text { Harmonisasi }\end{array}$} & \multicolumn{1}{c|}{ UUD 1945 } & \multicolumn{1}{c|}{ Cetak Biru MEA 2015 } \\
\hline $\begin{array}{l}\text { PENGATURAN } \\
\text { TENTANG } \\
\text { KEWENANGAN }\end{array}$ & $\begin{array}{l}\text { Butir 2 : } \\
\text { Cabang-cabang } \\
\text { produksi yang penting } \\
\text { bagi negara dan yang } \\
\text { menguasai hajat hidup } \\
\text { orang banyak dikuasai } \\
\text { oleh negara. }\end{array}$ & $\begin{array}{l}\text { Kerangka Kerja 2: } \\
\text { ASEAN sebagai kawasan } \\
\text { yang tinggi, dengan elemen } \\
\text { peraturan kan saing ekonomi } \\
\text { perlindungan konsumen, hak } \\
\text { atas kekayaan intelektual, } \\
\text { pengembangan infrastruktur, } \\
\text { perpajakan dan } \text { e-commerce. }\end{array}$ \\
\hline
\end{tabular}

Berdasar pada isi dari UUD 1945 butir 2 di atas dapat kita lihat bahwa kewenangan dalam mengatur seluruh cabang-cabang produksi yang penting bagi negara dan yang menguasai hajat hidup orang banyak dikuasai oleh negara. Hanya perusahaan yang tidak menguasai hajat hidup orang banyak boleh ada di tangan orang-seorang. Perekonomian berdasar atas demokrasi ekonomi, kemakmuran bagi semua orang. Sebab itulah UUD 1945 mengharuskan bahwa cabang-cabang produksi yang penting tersebut dikuasai oleh negara, Kalau tidak, tampuk produksi jatuh ke tangan orang seorang yang berkuasa dan rakyat banyak ditindas.

Pengaturan tentang kewenangan dalam cetak biru MEA 2015 dapat kita lihat dalam kerangka kerja butir 2 diserahkan kepada kompetisi dalam pasar dengan elemen peraturan kompetisi, perlindungan konsumen, hak atas kekayaan intelektual, pengembangan infrastruktur, perpajakan dan $e$ commerce yang akan memfasilitasi jalannya kompetisi tersebut termasuk aturan main didalamnya. Pasar bebas dengan konsep penghapusan tarif dan 
non tarif ini akan membentuk suatu iklim kompetisi di antara sesama negara anggota ASEAN. Masing-masing negara akan bersaing untuk meningkatkan keunggulan komparatif kawasan, baik dari sisi produksi barang, jasa dan sumber daya manusianya. Ketika sebuah negara tidak mampu melakukan peningkatan kualitasnya untuk memunyai keunggulan komparatif maka akan terjadi gelombang masalah-masalah sosial kemasyarakatan, ekonomi dan krisis kebangsaan, karena tujuan dari MEA 2015 adalah pasar bebas di mana produsen yang mampu bersaing, mampu mengikuti aturan main kompetisilah yang akan mendominasi dan memonopoli pasar. Sementara bagi produk yang kalah bersaing akan menjadi korban dari sebuah proses integrasi. Hal ini jelas akan mencederai cita-cita demokrasi ekonomi.

\section{Tabel 4.}

Disharmonisasi UUD 1945 dengan Cetak Biru MEA 2015 dengan Tolok Ukur Harmonisasi dari Aspek Tujuan Pengaturan

\begin{tabular}{|c|c|c|}
\hline $\begin{array}{c}\text { Fokus } \\
\text { Harmonisasi } \\
\end{array}$ & UUD 1945 & Cetak Biru MEA 2015 \\
\hline $\begin{array}{l}\text { TUJUAN } \\
\text { PENGATURAN }\end{array}$ & $\begin{array}{l}\text { Butir 3: } \\
\text { Bumi dan air dan } \\
\text { kekayaan alam yang } \\
\text { terkandung didalamnya } \\
\text { dikuasai oleh negara } \\
\text { dan dipergunakan } \\
\text { untuk sebesar-besar } \\
\text { kemakmuran rakyat. }\end{array}$ & $\begin{array}{l}\text { Kerangka Kerja } 3: \\
\text { ASEAN sebagai kawasan } \\
\text { dengan perkembangan } \\
\text { ekonomi yang merata dengan } \\
\text { elemen pengembangan usaha } \\
\text { kecil dan menengah, dan } \\
\text { prakarsa integrasi ASEAN } \\
\text { untuk negara-negara CLMV } \\
\text { yang termuat dalam Initiative } \\
\text { for ASEAN Integration. }\end{array}$ \\
\hline
\end{tabular}

Secara jelas UUD 1945 menjelaskan bahwa tujuan dari pengaturan terhadap pengelolaan sumber daya alam Indonesia, baik sumber daya alam hayati maupun sumber daya alam non hayati yang meliputi bumi dan air dan kekayaan alam yang terkandung dalam bumi adalah pokok-pokok kemakmuran rakyat. Sebab itu harus dikuasai oleh negara dan dipergunakan untuk sebesar-besar dengan tujuan memakmurkan rakyat. 
Berdasarkan isi dari cetak biru MEA 2015 dengan kerangka kerja butir ke-3 apabila dilihat dari sisi tujuan pengaturannya secara kontekstual tampak ideal dimana hal ini diperuntukkkan bagi perkembangan ekonomi yang merata diseluruh negara-negara anggota ASEAN termasuk negaranegara CLMV (Cambodia, Laos, Myanmar dan Vietnam) sebagai anggota bungsu di ASEAN. Perkembangan ekonomi yang merata ini akan dibangun berdasarkan elemen pengembangan usaha kecil dan menengah. Akan tetapi gambaran tentang pasar bebas yang menuntut terjadinya penghapusan tarif dan non tarif di mana market access terbuka lebar maka akan terjadi persaingan dari para pemilik modal yang hanya berorientasi pada keuntungan semata. Di mana faktor keuntungan tersebut akan berjalan sesuai dengan operasi pasar tanpa memandang berbagai kesenjangan kemampuan dan kapasitas tadi. Komponen produksi yang akan mendapat banyak keuntungan sepenuhnya akan menjadi kewenangan perusahaan multinasional. Berdasarkan fakta tersebut akan sulit tercapai sebuah perkembangan ekonomi yang merata dengan melibatkan elemen pengembangan usaha kecil dan menengah, karena pasar akan diarahkan dari, untuk dan oleh para pemilik modal saja.

\section{Tabel 5.}

Disharmonisasi UUD 1945 dengan Cetak Biru MEA 2015 dengan Tolok Ukur Harmonisasi dari Aspek Keberpihakan Pengaturan terhadap Lingkungan dan Masyarakat Sekitar.

\begin{tabular}{|l|l|l|}
\hline \multicolumn{1}{|c|}{$\begin{array}{c}\text { Fokus } \\
\text { Harmonisasi }\end{array}$} & \multicolumn{1}{c|}{ UUD 1945 } & \multicolumn{2}{c|}{ Cetak Biru MEA 2015 } \\
\hline KEBERPIHAKAN & Butir 4 : & Kerangka Kerja 4 : \\
PENGATURAN & $\begin{array}{l}\text { Perekonomian nasional } \\
\text { TERHADAP }\end{array}$ & ASEAN sebagai kawasan \\
diselenggarakan & yang terintegrasi secara \\
LINGKUNGAN & berdasar atas demokrasi & penuh dengan \\
DAN & ekonomi dengan & perekonomian global \\
MASYARAKAT & prinsip kebersamaan, & dengan elemen pendekatan \\
SEKITAR & efisiensi berkeadilan, & koheren dengan ekonomi di \\
& berkelanjutan, & $\begin{array}{l}\text { luar kawasan, dan } \\
\text { meningkatkan peran serta }\end{array}$ \\
\hline
\end{tabular}




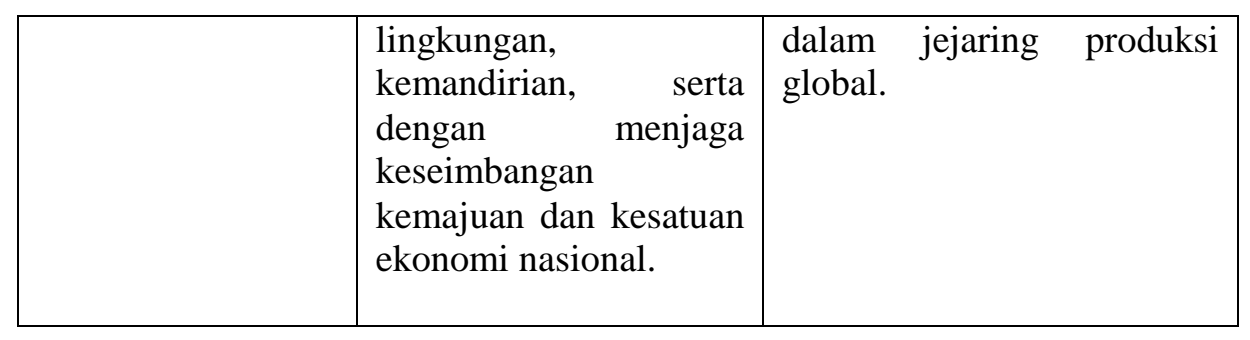

Keberpihakan pengaturan terhadap lingkungan dan masyarakat sekitar secara ideal dan selaras dituangkan di dalam Pasal 33 (4) UUD 1945, sebagaimana tersebut di atas. Isi pasal menyatakan bahwa perekonomian nasional harus diselenggarakan berdasar atas demokrasi ekonomi dengan prinsip kebersamaan, efisiensi berkeadilan, berkelanjutan, berwawasan lingkungan, kemandirian, serta dengan menjaga keseimbangan kemajuan dan kesatuan ekonomi nasional.

Cetak biru MEA 2015 dalam hal keberpihakannya terhadap lingkungan masyarakat sekitar dapat kita lihat dalam kerangka kerja 4 di mana ASEAN akan dijadikan kawasan yang terintegrasi secara penuh dengan perekonomian global dengan elemen pendekatan koheren dengan ekonomi di luar kawasan, dan meningkatkan peran serta dalam jejaring produksi global. Akan terjadi mobilisasi besar-besaran sebagai akibat dari penghapusan hambatan tarif dan non tarif berbagai produk, jasa, investasi dan tenaga kerja. Di sini akan memunculkan fakta bahwa hanya produk, jasa, investasi dan tenaga kerja yang terampil dan profesional saja yang akan diserap oleh pasar. Ketimpangan sosial akan terjadi dan mengancam pembangunan ekonomi yang akan memperparah kemiskinan, pengangguran, kelaparan dan penyakit.

Berbagai faktor penyebab terjadinya dan bentuk-bentuk disharmonisasi ketentuan tersebut menunjukkan bahwa perlu adanya harmonisasi hukum agar penerimaan sebuah ketentuan internasional dan ketentuan nasional dapat selaras dalam pencapaian hukum itu sendiri. Penerapan berbagai aturan secara bersama-sama tanpa upaya harmonisasi atau penyelerasan sudah barang tentu akan menimbulkan masalah, seperti benturan kepentingan antara lembaga dan stakeholder. Hal itu disebabkan masing-masing peraturan perundang-undangan memiliki tujuan, strategi 
untuk pencapaian tujuan, dan pedoman untuk melaksanakan strategi. Ketiga hal tersebut sering dirumuskan dalam bentuk kebijakan-kebijakan, baik kebijakan yang bersifat tetap atau regulatory policies yang diterapkan dalam berbagai bentuk peraturan pelaksanaan dari peraturan yang lebih tinggi tingkatannya, maupun kebijakn yang besifat tidak tetap, yaitu yang mudah diubah dalam rangka mengikuti perkembangan masyarakat. ${ }^{19}$

Harmonisasi berbagai peraturan perundang-undangan tidaklah mudah hal ini memerlukan langkah-langkah dan metode yang tepat, sesuai dengan prinsip-prinsip dasar dari pengkajian ilmu pengetahuan hukum. Harmonisasi hukum harus mengesampingkan kepentingan-kepentingan sektoral, kepentingan-kepentingan tertentu, karena untuk mengharmoniskan peraturan perundang-undangan, semua pihak terkait harus memandang sebuah peraturan dibuat untuk ;

a. kepentingan rakyat indonesia secara keseluruhan;

b. menghindari biaya besar yang berakibat pembebanan kepada masyarakat, dan

c. memperhatikan akibat yang timbul dari ditetapkannya peraturan perundang-undangan tersebut terhadap kerusakan lingkungan.

Harmonisasi hukum sangat menentukan keberadaan keberhasilan negara hukum dalam mengatur berbagai persoalan. Pemikiran ini jika dihubungkan dengan perspektif negara hukum, pembentukan hukum dan supremasi hukum atau rule of law harus ditegakkan secara konsekuen, supaya hukum berfungsi mengendalikan, mengawasi dan membatasi penguasa. Hukum tidak boleh digunakan sebagai instrumen politik untuk kepentingan politik tertentu termasuk kekuasaan. Oleh karena itu, negara adalah komponen utama yang harus menjadi instrumen pengatur dan pengendali kekuasaan negara. Dalam penyelenggaraan pemerintahan negara atau praktik-praktik ketatanegaraan, secara teoretis terdapat tiga prinsip utama yang harus digunakan sebagai landasan. Pertama, negara demokrasi, kedua negara hukum, dan sistem konstitusional. Negara demokrasi, negara hukum dan sistem konstitusional merupakan prinsip utama yang bertujuan

${ }^{19}$ Ermawaty Munir, Eksistensi UUD dan Tap MPR dalam sistem perundang-undangan dan dalam mekanisme ketatanegaraan Indonesia 1960-2000. Ringkasan desertasi. (Jakarta: Pascasarjana UI, 2000), hlm.1 sebagaimana dikutip dalam Heryandi, Loc.Cit. hlm. 19. 
membatasi kekuasaan atau mencegah dipraktikkannya kekuasaan pemerintah yang bersifat absolut dan otoriter. ${ }^{20}$

Berdasarkan uraian di atas sepatutnyalah Indonesia sebagai bagian dari masyarakat internasional bersifat kritis dalam menelaah aturan-aturan internasional yang tidak sesuai dengan cita-cita bangsa sebagaimana tertuang di dalam UUD 1945. Termasuk kritis terhadap aturan main dalam upayanya menuju integrasi ekonomi menuju MEA 2015. Indonesia harus mampu jeli melihat peluang, hambatan dan tantangan ketika memberikan komitmennya dalam sebuah sebuah peraturan internasional. Penguatan kapasitas dan kapabilitas para negosiator Indonesia harus terus ditingkatkan sehingga kita mampu menjadi negara yang mampu mewarnai bukan hanya sekedar terwarnai di tengah-tengah arus globalisasi tanpa bisa mengambil manfaat dari skenario globalisasi ekonomi. Melakukan banyak persiapan untuk menghadapi berbagai tantangan, memberikan solusi-solusi konkrit dilapangan untuk menjawab berbagai krisis kebangsaan di tengah-tengah arus globalisasi.

\section{Peraturan-Peraturan Nasional yang Berkaitan dengan MEA 2015}

Berikut adalah beberapa identifikasi peraturan-peraturan nasional yang berhubungan dengan MEA 2015 sebagai salah satu upaya pemerintah dalam menghadapi serbuan produk-produk ASEAN, antara lain;

1. Undang-Undang No. 38 Tahun 2008 tentang Pengesahan Charter of the Association of Southteast Asian Nations (Piagam Perhimpunan Bangsabangsa Asia Tenggara);

2. Inpres No. 5 Tahun 2008 tentang Fokus Program Ekonomi tahun 20082009;

3. Inpres No. 11 Tahun 2011 tentang Pelaksanaan Komitmen Cetak Biru MEA;dan

4. Keppres No. 23 Tahun 2012 tentang Susunan Keanggotaan Sekretariat Nasional ASEAN.

20 Loc. Cit., DPD RI, Naskah akademik RUU tentang sistem pembentukan peraturan perundang-undangan, (Jakarta, DPR RI, 2010), hlm. 10-11. Sebagaimana dikutip dalam Heryandi, hlm. 21. 


\section{Penutup}

Berdasarkan uraian pembahasan dan uraian pada bab-bab sebelumnya yang merupakan analisis terhadap rumusan masalah, teori-teori, aturan hukum internasional dan hukum nasional serta hasil pembahasan dan penelitian, maka kesimpulan dalam penelitian ini adalah:

Terdapat disharmonisasi antara UUD 1945 dengan ketentuan internasional tentang MEA 2015 di mana aturan tentang masalah perekonomian dan kesejahteraan sosial dalam UUD 1945 tercantum dalam Bab XIV Perekonomian Nasional dan Kesejahteraan Sosial, Pasal 33 (1), (2), (3) dan (4), sementara berdasarkan cetak biru MEA 2015 ini memuat empat kerangka kerja atau pilar MEA. Disharmonisasi kedua ketentuan tersebut terdapat dalam 4 (empat) hal yang menjadi fokus harmonisasi yaitu dari aspek asas hukumnya, pengaturan tentang kewenangan, tujuan pengaturan dan keberpihakan pengaturan terhadap lingkungan dan masyarakat sekitar.

\section{Daftar Pustaka}

\section{A. Buku}

Muhammad, Abdulkadir, 2004, Hukum dan Penelitian Hukum, Bandung: PT Citra Aditya Bakti.

Yasir, Armen, 2014, Hukum Perundang-undangan, Bandar Lampung: Justice Publisher.

Asian Forum and Human Rights Development, 2010, Rights Now: A Training Manual on ASEAN Human Rights mechanism, Hand Out Material, Thailand: Association of Southeast ASEAN Nations (ASEAN).

Nasution, Bahder Johan, 2008, Metode Penelitian Hukum, Bandung: Mandar Maju.

CPF Luhulima, Dewi F.A., Ikrar Nusa B, Yasmin S.,Ratna Shofi I, Masyarakat Asia Tenggara menuju komunitas ASEAN 2015. Jakarta: P2P-LIPI dan Pustaka Pelajar.

Departemen Luar Negeri Republik Indonesia (DEPLU RI), 2010, ASEAN selayang Pandang, Jakarta: Direktorat Jenderal Kerjasama ASEAN. 
Direktorat kerjasama ASEAN, 2008, Kenali ASEAN Kita, Jakarta: Kementerian Luar Negeri RI.

Heryandi, 2011, Harmonisasi Hukum Pengelolaan Pertambangan Minyak dan Gas Bumi Lepas Pantai Indonesia, Bandar Lampung: Penerbit Universitas Lampung.

Goesniadhie, Kusnu, 2006, Harmonisasi Hukum dalam Persepektif Perundang-undangan (Lex Spesialis Suatu Masalah), Surabaya.

Marzuki, Peter Mahmud, 2011, Penelitian Hukum, Jakarta: Kencana.

Sjamsul arifin, Rizal A Djaafara, Aida S Budiman, 2009, Masyarakat Ekonomi Asean 2015 Memperkuat Sinergi ASEAN di Tengah Kompetisi Global, Jakarta: Elex Media komputindo.

Sjamsumar Dam, Riswandi, 1996, Kerjasama ASEAN Latar Belakang, Perkembangan dan Masa Depan, Jakarta: Ghalia Indonesia.

Soerjono Soekanto, 2007, Pengantar Penelitian Hukum, Jakarta: UI Press.

\section{B. Aturan Hukum}

Undang-Undang Dasar 1945

Deklarasi ASEAN 1967

ASEAN Charter (Piagam ASEAN)

Declaration of ASEAN Concord II (Bali Concord II) 2003

\section{Internet}

Kementerian Luar Negeri Indonesia, Sejarah ASEAN, http://www.kemlu.go.id/Pages/Asean.aspx?IDP=6\&1=id.

Kementerian Luar Negeri Indonesia, Sejarah ASEAN, http://www.kemlu.go.id/pages/Asean.aspx?IDP=6\&1=id.

Direktorat Jenderal Kerjasama ASEAN, ASEAN Selayang Pandang, melalui littp://kemiu go.id/Documents/ASEAN``20Selayan,$\% 20$ Pandang,.doc.

Ratifikasi Piagam ASEAN, lihat http://id.wikipedia.org/wiki/Piagam ASEAN.

e-book. Departemen Perdagangan Republik Indonesia. Menuju Asean Economic Community 2015. 